\section{Panhandle PCR}

\section{Douglas H. Jones}

Department of Pediatrics, University of Iowa College of Medicine, Iowa City, Iowa 52242
PCR permits highly specific DNA amplification in vitro. PCR occurs by primer extension from each end of a sequence and therefore requires knowledge of those ends. ${ }^{(1)}$ Several methods have been developed for PCR amplification of unknown DNA that flanks one end of a known sequence. ${ }^{(2-25)}$ These methods extend the application of PCR to the retrieval of DNA where only one end of the DNA sequence is known, so that one can use PCR to "walk" along an uncharacterized stretch of DNA without screening a library for overlapping clones. None of the existing methods, apart from panhandle PCR, has permitted the highly specific PCR amplification of $>3.0 \mathrm{~kb}$ of human genomic DNA that flanks a known site. This paper describes a protocol for panhandle PCR that permits the highly specific PCR amplification of $\leqslant 4.4 \mathrm{~kb}$ of DNA that flanks a known site directly from bulk human genomic DNA.

\section{REAGENTS}

1. Restriction endonucleases (New England BioLabs, Beverly, MA)

2. Calf intestinal alkaline phosphatase (Boehringer Mannheim Biochemicals, Indianapolis, IN)

3. Geneclean II (Bio 101, La Jolla, CA)

4. TE (10 mM Tris- $\mathrm{HCl}$ at $\mathrm{pH} 8,1 \mathrm{~mm}$ EDTA)

5. T4 DNA ligase (Boehringer Mannheim Biochemicals, Indianapolis, IN)

6. AmpliTaq polymerase, $5 \mathrm{U} / \mu \mathrm{l}$ (Cetus, Norwalk CT)

7. $10 \times \mathrm{Taq}$ polymerase buffer $(500 \mathrm{mM} \mathrm{KCl}, 100 \mathrm{~mm}$ Tris- $\mathrm{Cl}$ at $\mathrm{pH} 8.3,15$ $\mathrm{mM} \mathrm{MgCl} 2,0.1 \%(\mathrm{wt} / \mathrm{vol})$ gelatin

$8100 \mathrm{~mm}$ each of dATP, dCTP, dGTP, and dTTP (Boehringer Mannheim, Indianapolis, IN)

9. Oligonucleotides (Midland Certified Reagent Company, Midland, TX)

10. Agarose

11. Ethidium bromide

12. TAE buffer ${ }^{(26)}$

13. Long, thin micropipette tips (Gel loader tips T-010; Phenix Research Products, Hayward, CA, USA)

\section{PROTOCOL}

Panhandle PCR is illustrated in Figure 1. Briefly, genomic DNA is subjected to restriction endonuclease digestion that generates a $5^{\prime}$ overhang and dephosphorylation with calf intestinal alkaline phosphatase (step 1). Following glass bead extraction to remove the alkaline phosphatase, the cleaved DNA undergoes T4 DNA ligase-mediated joining to a single-stranded oligonucleotide to create 3 '-end extensions (step 2). These end extensions are complementary to the known sequence located upstream to the unknown DNA of interest. Following glass bead extraction to remove unligated oligonucleotides, the mixture is denatured and reannealed under dilute conditions and high stringency in Taq DNA polymerase buffer with Taq DNA polymerase and the four dNTPs. Those single strands that contain the complement to the 3 '-end extension form a stem-loop with a recessed $3^{\prime}$ end that primes template-directed DNA polymerization. This polymerization attaches known DNA to the uncharacterized end of the flanking unknown DNA (step 3). Because this polymerization results in known DNA being positioned on both sides of the unknown flanking DNA, PCR followed by nested PCR can be used to amplify the unknown DNA (steps 4,5). Two primers are used during each PCR amplification. Amplification using a single primer works poorly because relatively large inverted repeats in PCR product ends impede amplification. The steps outlined above are detailed below. These steps correspond to those in Figure 1. 


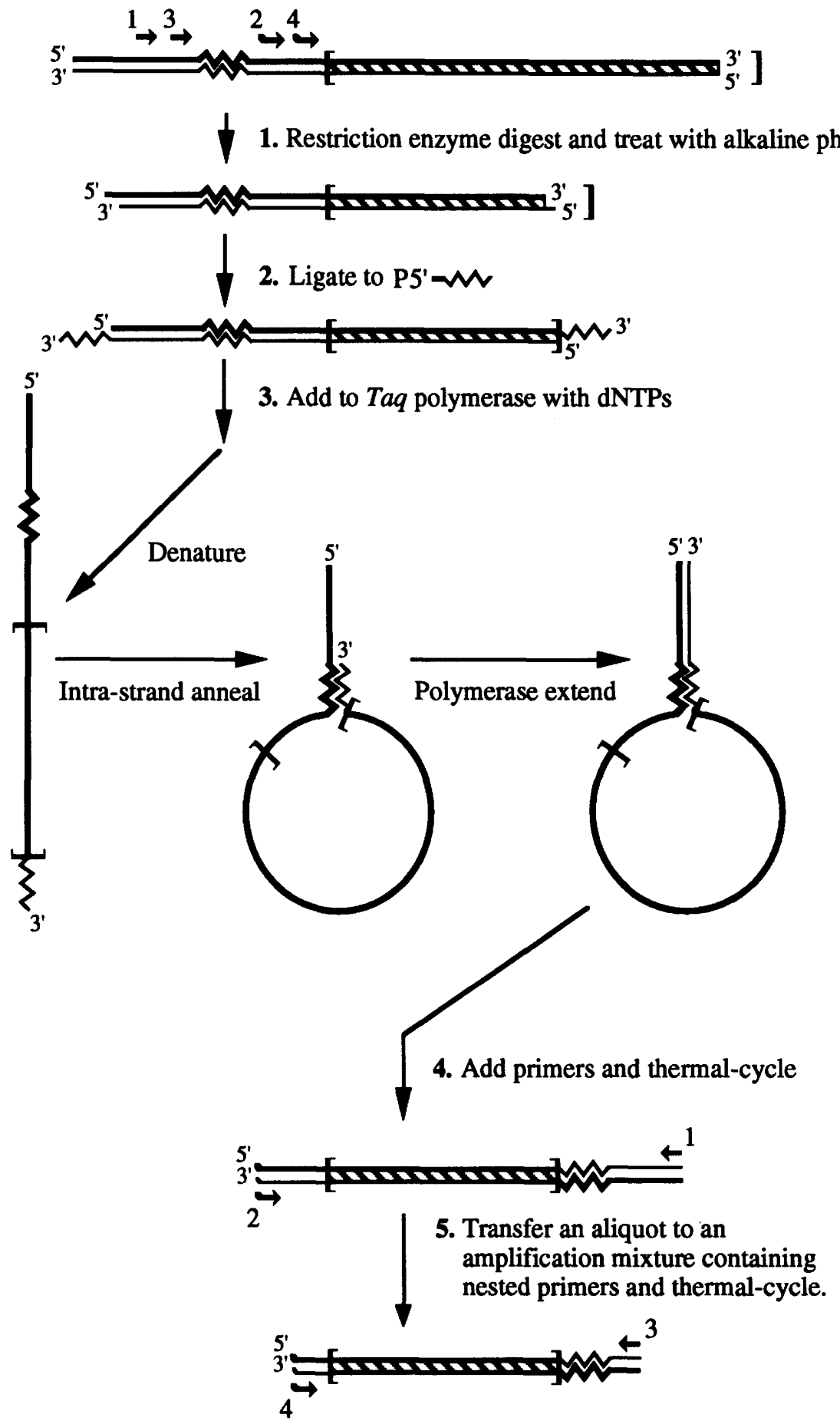

FICURE 1 Panhandle PCR. The numbered steps correspond to the numbered steps in the Protocol. The two complementary strands of genomic DNA are represented by thin and thick lines. The unknown region of genomic DNA is enclosed by brackets and is hatched when doublestranded. The jagged portion of the thick line represents the annealing region for the ligated oligonucleotide. The PCR primers are numbered arrows. The location of the primers in relation to the relevant strands of genomic DNA are shown on top of the diagram for step 1, and the primers are not used until step 4 . One or two nucleotides are added to the 5 ' ends of primers 2 and 4 that are not complementary to their original template and are represented by upended $5^{\prime}$ ends.

Figure 2 shows the positioning and sequences of a set of oligonucleotides that were used to amplify $4.4 \mathrm{~kb}$ of DNA flanking the primer annealing sites following digestion of human genomic DNA with the restriction endonuclease Bcll. ${ }^{(24)}$ 


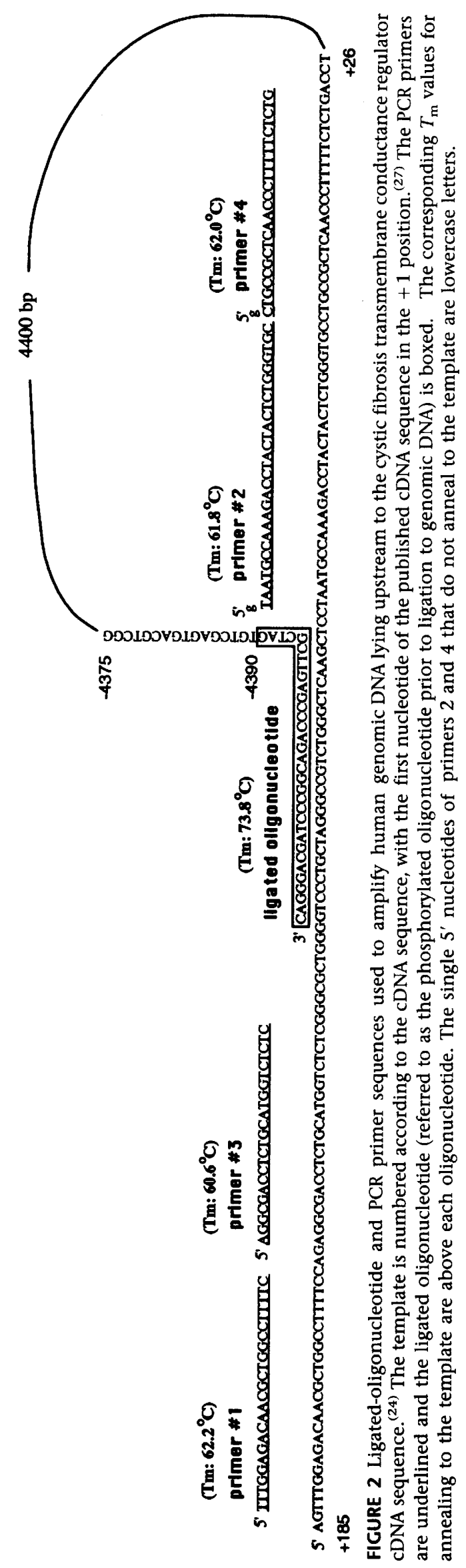


1. Restriction Endonuclease Digestion Followed by Calf Intestinal Alkaline Phosphatase Treatment Digest $5 \mu \mathrm{g}$ of human genomic DNA with 20-40 units of a restriction endonuclease that yields a $5^{\prime}$ overhang in $100 \mu \mathrm{l}$ for $2 \mathrm{hr}$. Dephosphorylate the digested genomic DNA by adding 0.05 units of calf intestinal alkaline phosphatase (Boehringer Mannheim Biochemicals; add $5 \mu \mathrm{l}$ of $0.01 \mathrm{U} / \mu \mathrm{l}$; dilute the stock $1 \mathrm{U} / \mu \mathrm{l}, 1: 100$ in TE) directly to the digest, resulting in a total volume of $105 \mu$. Incubate the mixture at $37^{\circ} \mathrm{C}$ for $30 \mathrm{~min}$. Extract the DNA using Geneclean (Bio 101, La Jolla, CA), and suspend the DNA in $50 \mu \mathrm{l}$ of TE. Freeze $25 \mu \mathrm{l}$ of the Geneclean product for later use as the template control. Note: (1) We purchase our genomic DNA from Clontech (Palo Alto, CA) for convenience; this DNA is made according to the method of Blin and Stafford. ${ }^{(28)}$ (2) The restriction endonucleases typically have a 6-nucleotide recognition domain and generate a 4-nucleotide long 5 '-end extension. Enzymes used to generate panhandle PCR products have included HindIII, $B a m H I, B c l I, B g l I I, A v r I I$, and XbaI. ${ }^{(23,24)}$ (3) Glass bead extraction using Geneclean removes small DNA fragments and the calf intestinal alkaline phosphatase.

2. Ligation of the Phosphorylated Oligonucleotide Ligate the remaining $25 \mu \mathrm{l}$ of genomic DNA (containing $\sim 2.5 \mu \mathrm{g}$ of DNA) to 50 -fold molar excess of a $5^{\prime}$ phosphorylated oligonucleotide in T4 DNA ligase buffer $(50 \mathrm{~mm} \mathrm{Tris-} \mathrm{HCl}$ at $\mathrm{pH} 7.6,10 \mathrm{~mm} \mathrm{MgCl}, 0.5 \mathrm{~mm}$ ATP, and $10 \mathrm{~mm}$ dithiothreitol) using one Weiss unit T4 DNA ligase (Boehringer Mannheim Biochemicals) at $23^{\circ} \mathrm{C}$ for $4 \mathrm{hr}$ or overnight at $16^{\circ} \mathrm{C}$. Purify the ligation mixture using Geneclean and suspend it in $25 \mu \mathrm{l}$ of TE. This is the template for step 3. Note: (1) A restriction endonuclease with a 6-nucleotide recognition domain cuts genomic DNA to an average size of $\sim 4.0 \mathrm{~kb}$. A 50 -fold molar excess of a single-stranded 33 nucleotide long phosphorylated oligonucleotide (as shown in Fig. 2) requires $\sim 516 \mathrm{ng}$ of the oligonucleotide. These calculations are a rough estimates, and it is not necessary to make a more precise calculation that compensates for poor Geneclean recovery of DNA $<500 \mathrm{bp}$ and for a restriction endonucleasecutting frequency that varies with the nucleotide composition of the restriction endonuclease recognition domain [attributable in part to the $\mathrm{A} / \mathrm{T}$ predominance $(59 \%)$ of mammalian genomes ${ }^{(29)}$. (2) The oligonucleotide with a phosphorylated $5^{\prime}$ end is generated during oligonucleotide synthesis by addition of a phosphorylated phosphoramidite during oligonucleotide synthesis. Alternatively, it can be $5^{\prime}$ phosphorylated using T4 polynucleotide kinase as follows: Incubate $2 \mu \mathrm{g}$ of the oligonucleotide with 10 units of T4 polynucleotide kinase (New England BioLabs, Beverly, MA) in kinase buffer (50 mM Tris- $\mathrm{HCl}$ at pH 7.6, $10 \mathrm{mM} \mathrm{MgCl}_{2}, 1 \mathrm{~mm}$ ATP, and $5 \mathrm{~mm}$ dithiothreitol) at $37^{\circ} \mathrm{C}$ for $30 \mathrm{~min}$. Then, inactivate the $\mathrm{T} 4$ polynucleotide kinase by heating at $68^{\circ} \mathrm{C}$ for $10 \mathrm{~min}$ and store at $-20^{\circ} \mathrm{C}$ until it is used. (3) The $5^{\prime}$ phosphorylated oligonucleotide has a $5^{\prime}$ end that is complementary to the singlestranded ends of restriction endonuclease digested genomic DNA generated in step 1. A single phosphorylated oligonucleotide can be used with genomic DNA that has undergone digestion with one of several restriction enzymes. For instance, an oligonucleotide whose $5^{\prime}$ end consists of 5'P-GATC can be ligated to genomic DNA that has been digested with either BamHI, Bcll, or BglII. An oligonucleotide whose $5^{\prime}$ end consists of 5'P-CTAG can be ligated to genomic DNA that has been digested with either XbaI, AvrII, NheI, or SpeI. (4) The phosphorylated oligonucleotide is designed so that the $T_{\mathrm{m}}$ of the domain that undergoes annealing during panhandle formation (step 3 ) is $\sim 74^{\circ} \mathrm{C} . T_{\mathrm{m}}$ values for the phosphorylated oligonucleotide and primers are calculated using the computer program OLIGO (National BioSciences, Hamel, NM). (5) One application of this method is the amplification of a gene promoter from human genomic DNA using cDNA sequence data. In this application, the cDNA sequence is used to design primers that will amplify the genomic DNA 
located $5^{\prime}$ to the cDNA sequence. It is important to consider that the cDNA is usually not intact in the genome, because it is interrupted by one or more introns. The presence of an intron within a primer annealing domain will prevent this method from working. Therefore, it is advisable to amplify the primer annealing domains (the DNA sequence to which primers $1-4$ and the phosphorylated oligonucleotide will anneal), directly from genomic DNA using conventional PCR prior to carrying out panhandle PCR, to make sure that the predicted piece (typically $150-200 \mathrm{bp}$ ) is obtained. This precaution will ensure that this stretch of DNA is intact in the genome, and not interrupted by an intron.

3. Panhandle Formation Add $18 \mu \mathrm{l}$ of $\mathrm{H}_{2} \mathrm{O}$ to a $25-\mu \mathrm{l}$ aliquot of $2 \times$ PCR mixture (1.25 units of Taq DNA polymerase [AmpliTaq, Perkin-Elmer Cetus, Norwalk CT), $100 \mathrm{~mm} \mathrm{KCl}, 20 \mathrm{mM}$ Tris- $\mathrm{HCl}$ at $\mathrm{pH} \mathrm{8.3,} 3 \mathrm{~mm} \mathrm{MgCl}, 0.02 \%$ (wt/vol) gelatin, $400 \mu \mathrm{M}$ of each dNTP]. Layer with approximately $50 \mu \mathrm{l}$ of mineral oil. Preheat the tube to $80^{\circ} \mathrm{C}$ prior to the addition of $2 \mu \mathrm{l}$ of template. Place the mixture in a thermal cycler and allow the following temperature transitions (Perkin Elmer Cetus): $95^{\circ} \mathrm{C}$ for $1 \mathrm{~min}$, followed by a 2 min ramp to $72^{\circ} \mathrm{C}$ for $30 \mathrm{sec}$, and then to an $80^{\circ} \mathrm{C}$ soak. Note: (1) The $2 \times$ PCR mixture aliquots can be prealiquoted and stored at $-20^{\circ} \mathrm{C}$ for $\leqslant 6$ months prior to use. (2) Maintaining the tube at $80^{\circ} \mathrm{C}$ before adding the template prevents nonspecific annealing and polymerization. ${ }^{(30)}(3)$ Because the genomic DNA concentration is $<4 \mathrm{ng} / \mu \mathrm{l}$, these denaturation and reannealing steps result in intrastrand annealing of the ligated synthetic oligonucleotide to its complementary sequence in the genomic DNA. ${ }^{(3)}$ This is followed by templatedirected polymerase extension of the recessed 3 ' end. (4) Two additional tubes, one containing the template control (genomic DNA that has been restriction endonuclease digested but not ligated to the phosphorylated oligonucleotide) and the other containing a reagent control (no DNA) should be processed concurrently as controls.

4. Initial Amplification Add 12.5 pmoles of each primer (primers 1 and 2 in Fig. 1) in a total volume of $5 \mu \mathrm{l}$ of $\mathrm{H}_{2} \mathrm{O}$, under the mineral oil while each tube from the previous step remains in the heat block at $80^{\circ} \mathrm{C}$. Cycle $\left(95^{\circ} \mathrm{C}\right.$ for 30 sec, $60^{\circ} \mathrm{C}$ for $30 \mathrm{sec}$, and $72^{\circ} \mathrm{C}$ for $4 \mathrm{~min}$ ) for 30 cycles followed by a final extension at $72^{\circ} \mathrm{C}$ for $7 \mathrm{~min}$, then, go to an $80^{\circ} \mathrm{C}$ soak. Note: (1) Final concentrations are $0.25 \mu \mathrm{M}$ of each primer with $200 \mu \mathrm{M}$ of each dNTP. (2) Following thermal cycling, cooling the reagents to $4^{\circ} \mathrm{C}$ (as opposed to keeping the tubes at $80^{\circ} \mathrm{C}$ ) at the end of this step also works well. (3) A hot start is carried out by maintaining the temperature of the fully constituted polymerase reactants above $80^{\circ} \mathrm{C}$ prior to the primer annealing step. This eliminates priming at low stringency, preventing the generation of nonspecific products. ${ }^{(30)}$ (4) Primers in each amplification are designed so that their $T_{\mathrm{m}}$ is $\sim 62^{\circ} \mathrm{C}$ (Fig. 2). The annealing temperature during the thermal cycling is $\sim 2^{\circ} \mathrm{C}$ below the primer $T_{\mathrm{m}} \mathrm{s}$. Primer 2 in this amplification and primer 4 in step 5 have 1-2 nucleotides added to each 5 ' end that do not anneal to the original template, and the $T_{\mathrm{m}}$ values used have not included these added nucleotides. These nucleotides are added as a precaution to prevent the possibility of a short circuiting of the amplification. Short circuiting could occur by the annealing of the $3^{\prime}$ end of one strand of a short nonspecific PCR product to the template, with this strand being complementary to the strand into which one of these primers was incorporated. It is an inexpensive precaution whose necessity has not been tested.

5. Nested Amplification Remove $1 \mu$ l of the unpurified initial PCR product by inserting a long, thin pipette tip through the mineral oil layer, and place it in a corresponding PCR tube containing nested primers (primers 3 and 4 in Fig. 1) preheated to $80^{\circ} \mathrm{C}$ with the same enzyme, reagents, and primer concentrations as in the first PCR amplification. Tubes with the nested primers 
undergo 35 PCR thermal cycles with cycling parameters identical to those used in the initial amplification. Note: PCR products are detected by agarose gel electrophoresis followed by ethidium bromide staining. If multiple bands are seen, raising the annealing temperature in this nested amplification by $1-2^{\circ} \mathrm{C}$ will frequently eliminate the shorter products. The PCR product either can be directly sequenced or cloned prior to sequencing. ${ }^{(31,32)}$ Once the unknown end is sequenced, a new primer can be made so the sequence can be amplified from genomic DNA using conventional PCR.

\section{CONCLUSION}

Panhandle PCR amplifies $>3.0 \mathrm{~kb}$ of human genomic DNA that flanks a known site. High specificity occurs because full nested amplifications can be carried out. This has permitted panhandle PCR to amplify near the limit of what can be accomplished using Taq DNA polymerase and routine buffer conditions.

Another method that amplifies of $>2.0 \mathrm{~kb}$ of human genomic DNA that flanks a known site is the related targeted inverted repeat amplification method. ${ }^{(25)}$ Targeted inverted repeat amplification shares with panhandle PCR the restriction endonuclease digestion of DNA followed by the ligation of an oligonucleotide that is complementary to the known sequence. In contrast to panhandle PCR, the 5' ends of genomic DNA are extended by ligation to an oligonucleotide instead of the $3^{\prime}$ ends, so that denaturation and intrastrand annealing results in the formation of a stem-loop structure with a recessed and phosphorylated 5' end that can undergo template-directed ligation to a second oligonucleotide using a heat-stable ligase. These two oligonucleotides can then be used sequentially in single primer amplifications of the unknown flanking DNA.

Targeted inverted repeat amplification requires fewer primers than panhandle PCR and can be carried out using a shorter stretch of known sequence. Panhandle PCR has fewer steps and has amplified longer fragments using Taq DNA polymerase and routine buffer conditions. Panhandle PCR is, at this time, the preferred method unless a limited stretch of known sequence $(<150-200$ nucleotides) precludes its use. Applications of panhandle PCR include chromosome walking, retrieval of promoters and gene regulatory domains using cDNA data, determination of viral and transposon integration sites, and the retrieval and sequencing of unclonable DNA.

\section{ACKNOWLEDGMENTS}

This work was supported by National Institutes of Health grant RO1 HG00569 and the Roy J. Carver Charitable Trust.

\section{REFERENCES}

1. Mullis, K., F. Faloona, S. Scharf, R. Saiki, G. Horn, and H. Erlich. 1986. Specific enzymatic amplification of DNA in vitro: The polymerase chain reaction. Cold Spring Harbor Symp. on Quant. Biol. 51: 263-273.

2. Ochman, H., A.S. Gerber, and D.L. Hartl. 1988. Genetic applications of an inverse polymerase chain reaction. Genetics 120: 621-623.

3. Triglia, T., M.G. Peterson, and D.J. Kemp. 1988. A procedure for in vitro amplification of DNA segments that lie outside the boundaries of known sequences. Nucleic Acids Res. 16: 8186.

4. Silver, J. and V. Keerikatte. 1989. Novel use of polymerase chain reaction to amplify cellular DNA adjacent to an integrated provirus. J. Virol. 63: 1924-1928.

5 Frohman, M.A., M.K. Dush, and G.R. Martin. 1988. Rapid production of full-length cDNAs from rare transcripts: Amplification using a single gene-specific oligonucleotide primer. Proc. Natl. Acad. Sci. 85: 8998-9002.

6. Loh, E.Y., J.F. Elliott, S. Cwirla, L.L. Lanier, and M.M. Davis. 1989. Polymerase chain reaction with single sided specificity: Analysis of T cell receptor $\delta$ chain. Science 243: 217-220. 
7. Ohara, O., R.L. Dorit, and W. Gilbert. 1989. One-sided polymerase chain reaction: The amplification of cDNA. Proc. Natl. Acad. Sci. 86: 5673-5677.

8. Edwards, J.B.D.M., J. Delort, and J. Mallet. 1991. Oligodeoxyribonucleotide ligation to singlestranded cDNAs: A new tool for cloning 5 ' ends of mRNAs and for constructing cDNA libraries by in vitro amplification. Nucleic Acids Res. 19: 5227-5232.

9. Troutt, A.B., M.G. McHeyzer-Williams, B. Pulendran, and G.J.V. Nossal. 1992. Ligation-anchored PCR: A simple amplification technique with single-sided specificity. Proc. Natl. Acad. Sci. 89: 9823-9825.

10. Shyamala, V. and G.F-L. Ames. 1989. Genome walking by single-specific-primer polymerase chain reaction: SSP-PCR. Gene 84: 1-8.

11. Kalman M., E.T. Kalman, and M. Cashel. 1990. Polymerase chain reaction (PCR) amplification with a single specific primer. Biochem. Biophys. Res. Comm. 167: 504-506.

12. Roux, K.H. and P. Dhanarajan. 1990. A strategy for single site PCR amplification of dsDNA: Priming digested cloned or genomic DNA from an anchor-modified restriction site and a short internal sequence. BioTechniques 8: 48-57.

13. Riley, J., R. Butler, D. Ogilvie, R. Finniear, D. Jenner, S. Powell, R. Anand, J.C. Smith, and A.F. Markham. 1990. A novel, rapid method for the isolation of terminal sequences from yeast artificial chromosome (YAC) clones. Nucleic Acids Res. 18: 2887-2890.

14. Arnold, C., and I.J. Hodgson. 1991. Vectorette PCR: A novel approach to genomic walking. PCR Methods Applic. 1: 39-42.

15. Pfeifer, G.P., S.D. Steigerwald, P.R. Mueller, B. Wold, and A.D. Riggs. 1989. Genomic sequencing and methylation analysis by ligation mediated PCR. Science 246: 810-813.

16. Rosenthal, A. and D.S.C. Jones. 1990. Genomic walking and sequencing by oligocassette mediated polymerase chain reaction. Nucleic Acids Res. 18: 3095-3096.

17. Lagerstrom, M., J. Parik, H. Malmgren, J. Stewart, U. Pettersson, and U. Landegren 1991. Capture PCR: Efficient amplification of DNA fragments adjacent to a known sequence in human and YAC DNA. PCR Methods Applic. 1: 111-119.

18. Tormanen, V.T., P.M. Swiderski, B.E. Kaplan, G.P. Pfeifer, and A.D. Riggs. 1992. Extension product capture improves genomic sequencing and DNase I footprinting by ligation-mediated PCR. Nucleic Acids Res. 20: 5487-5488.

19. MacGregor, G.R. and P.A. Overbeek. 1991. Use of a simplified single-site PCR to facilitate cloning of genomic DNA sequences flanking a transgene integration site. PCR Methods Applic. 1: $129-135$.

20. Parker, J.D., P.S. Rabinovitch, and G.C. Burmer. 1991. Targeted gene walking polymerase chain reaction. Nucleic Acids Res. 19: 3055-3060.

21. Parks, C.L., L-S. Chang, and T. Shenk. 1991. A polymerase chain reaction mediated by a single primer: Cloning of genomic sequences adjacent to a serotonin receptor protein coding region. Nucleic Acids Res. 19: 7155-7160.

22. Sarkar, G., R.T. Turner, and M.E. Bolander. 1993. Restriction-site PCR: A direct method of unknown sequence retrieval adjacent to a known locus by using universal primers. $P C R$ Methods Applic. 2: 318-322.

23. Jones, D.H. and S.C. Winistorfer. 1992. Sequence specific generation of a DNA panhandle permits PCR amplification of unknown flanking DNA. Nucleic Acids Res. 20: 595-600.

24. Jones, D.H. and S.C. Winistorfer. 1993. Genome walking with 2- to 4-kb steps using panhandle PCR. PCR Methods Applic. 2: 197-203.

25. Jones, D.H. and S.C. Winistorfer. 1993. A method for the amplification of unknown flanking DNA: Targeted inverted repeat amplification. BioTechniques 15: 894-904.

26. Sambrook, J., E.F. Fritsch, and T. Maniatis. 1989. Molecular cloning: A laboratory manual, 2nd ed., p. B.23, Cold Spring Harbor Laboratory Press, Cold Spring Harbor, New York.

27. Riordan, J.R., J.M. Rommens, B-S. Kerem, N. Alon, R. Rozmahel, Z. Grzelczak, J. Zielenski, S. Lok, N. Plavsic, J-L. Chou, M.L. Drumm, M.C. Iannuzzi, F.S. Collins, and L-C. Tsui. 1989. Identification of the cystic fibrosis gene: Cloning and characterization of complementary DNA. Science 245: 1066-1073.

28. Blin, N. and D.W. Stafford. 1986. A general method for isolation of high molecular weight DNA from eukaryotes. Nucleic Acids Res. 3: 2303-2308.

29. Normore, W.M., H.S. Shapiro, and P. Setlow. 1976. CRC Handbook of Biochemistry and Molecular Biology (ed. G.D. Fastman), CRC Press, Boca Raton, FL.

30. Mullis, K.B. 1991. The polymerase chain reaction in an anemic mode: How to avoid cold oligodeoxyribonuclear fusion. PCR Methods Applic. 1: 1-4.

31. Costa, G.L. and M.P. Weiner. 1994. Protocols for cloning and analysis of blunt-ended PCRgenerated DNA fragments. PCR Methods Applic. 3: S95-S106.

32. Jones, D.H. 1994. DNA mutagenesis and recombination in vivo. PCR Methods Applic. 3: S141S148. 


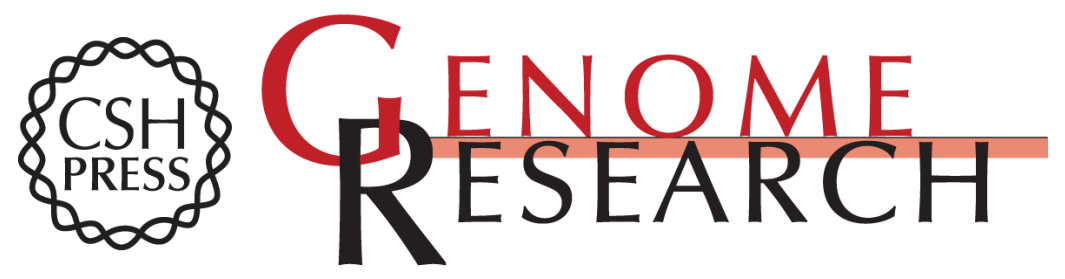

\section{Panhandle PCR.}

D H Jones

Genome Res. 1995 4: S195-S201

References This article cites 30 articles, 8 of which can be accessed free at:

http://genome.cshlp.org/content/4/5/S195.full.html\#ref-list-1

\section{License}

Email Alerting Receive free email alerts when new articles cite this article - sign up in the box at the Service top right corner of the article or click here.

\section{Affordable, Accurate Sequencing.}

To subscribe to Genome Research go to: https://genome.cshlp.org/subscriptions 